\title{
Type II cGMP-dependent protein kinase inhibits proliferation of the gastric cancer cell line BGC-823
}

\author{
YONG-CHANG CHEN, FENG REN, JIAN-RONG SANG, YAN TAO and WEN-RONG XU
}

School of Medical Science and Laboratory Medicine, Jiangsu University, Jiangsu 212013, P.R. China

Received December 17, 2009; Accepted February 2, 2010

DOI: $10.3892 / \mathrm{mmr}+00000266$

\begin{abstract}
Our previous studies have demonstrated that the expression and activity of protein kinase $\mathrm{G}$ (PKG) II are significantly lower in human gastric cancer cell lines than in normal cells. This study was designed to investigate the effect of PKG II activation on the proliferation of human cultured BGC-823 gastric cancer cells. An adenoviral construct encoding the PKG II gene (Ad-PKG II) was used to infect BGC-823 cells, and the activity of the enzyme was induced by cGMP analogue 8-pCPT-cGMP. The proliferation-inhibitory effect of PKG II was analyzed by the MTT assay, BrdU incorporation assay and detection of proliferating cell nuclear antigen (PCNA) expression. Colony formation in soft agarose was performed to analyze the effect of PKG II on the anchorage-independent growth of the cells. The effect of PKG II in vivo was investigated in an immunocompromised nude mice model, and its effect on the cell cycle was analyzed by flow cytometry. The results showed that Ad-PKG II infection increased the expression of PKG II in BGC-823 cells. The activation of PKG II by 8 -pCPT-cGMP caused a significant decrease in the number of live cells and inhibited DNA synthesis in individual cells. PKG II activation inhibited the EGF-induced increase in PCNA expression. The activation of PKG II also caused a significant inhibition of colony formation in soft agarose and significantly suppressed the in vivo growth of BGC-823 cells in immunocompromised nude mice. There was substantial cell arrest at the $\mathrm{G}_{1}$ phase and a decrease in the number of $\mathrm{S}$ phase cells in the Ad-PKG II/8-pCPT-cGMP-treated cells. These data indicate that the activation of PKG II by 8 -pCPT-cGMP inhibits the proliferation of human gastric cancer cells.
\end{abstract}

\section{Introduction}

Gastric cancer is one of the most common malignancies in the world, particularly in eastern Asian countries such as China,

Correspondence to: Dr Yong-Chang Chen, School of Medical Science and Laboratory Medicine, Jiangsu University, 301 Xue Road, Zhenjiang City, Jiangsu 212013, P.R. China

E-mail: ycchen54@ujs.edu.cn

Key words: protein kinase G II, adenovirus, gastric cancer cells, proliferation
Korea and Japan (1). Despite advances in its diagnosis and treatment, the prognosis for advanced gastric cancer remains poor, with a 5-year survival rate of less than $10 \%$ (2). In recent years, much evidence has clearly demonstrated that multiple genetic changes are responsible for the development and progression of gastric cancer (3).

Protein kinase $\mathrm{G}(\mathrm{PKG})$ is a serine-threonine kinase. To date, two types of PKG, PKG I and PKG II, have been identified in mammals $(4,5)$. PKG I is widely distributed and consists of $\mathrm{I} \alpha$ and $\mathrm{I} \beta$ isoforms $(6,7)$ arising from alternative splicing. Previous studies have found that PKG I expression is reduced in many tumors compared to respective normal tissue, and exogenous PKG I leads to decreased tumor growth and invasiveness in many cells including cardiomyocytes, mesangial cells, the pancreatic $\beta$-cell line and neutrophils (8-14). PKG I also has a role in inducing apoptosis in colon tumor cells treated with the phosphodiesterase inhibitor exisulind $(15,16)$. Thus, PKG I has been identified as a tumor suppressor (17-19).

Unlike PKG I, the expression of PKG II is more tissue restricted (20). As a structurally and functionally distinct membrane-bound enzyme (7,21), PKG II has been implicated in several physiological functions, including intestinal secretion, bone growth and learning and memory (22). In contrast to the well-proven antitumor effect of PKG I, no research data have clearly indicated an antitumor role for PKG II. However, research has indicated that PKG II has a role in regulating cell proliferation and apoptosis. For example, in cultured human prostatic stromal cells, PKG II inhibited proliferation and induced apoptosis $(23,24)$. PKG II activation also decreased proliferation in certain cell types (23-26). Recently, we found that the expression and activity of PKG II were significantly lower in human gastric cancer cell lines than in normal cells (27). These findings suggest that PKG II may be a potential tumor suppressor. Therefore, the present study was designed to elucidate the possible antitumor activity of PKG II.

\section{Materials and methods}

Cell lines and reagents. The human gastric cancer cell line BGC-823 was provided by the Institute of Cell Biology (Shanghai, China). Four- to six-week-old female BALB/c nude mice were purchased from the Center for Comparative Medicine of Yangzhou University, China. The adenoviral vector encoding either $\beta$-galactosidase (LacZ) or PKG II 
were kind gifts from Dr Gerry Boss and Dr Renate Pilz from the University of California (San Diego, CA). Dulbecco's modified Eagle's medium (DMEM) was from Gibco (Grand Island, NY), new-born calf serum (NBCS) was from Minhai Bio-engineering Co. (Lanzhou, China), the antibody against PKG II was from Abgent Biotechnology, the antibody against glyceraldehyde phosphate dehydrogenase (GAPDH) was from Kangcheng Co. (Hangzhou, China) and the horseradish peroxidase (HRP)-conjugated secondary antibody was from Jackson Immuno Research Laboratories (West Grove, PA). Propidium iodide (PI) and the cellular permeable cGMP analogue 8-pCPT-cGMP were from Calbiochem (San Diego, CA). EGF and fluorochrome Cy3, FITC, Hoechst 33342 were from Sigma (St. Louis, MO). Electrochemiluminescence (ECL) reagents were from Amersham Biosciences (Buckinghamshire, UK). All other reagents used were of analytical grade.

Cell culture and infection with adenoviral constructs. BGC-823 cells were cultured in DMEM supplemented with $10 \% \mathrm{NBCS}$ and maintained at $37^{\circ} \mathrm{C}$ in a humidified incubator with $95 \%$ air and $5 \% \mathrm{CO}_{2}$. The medium was changed every two days, and the cells were subcultured at confluence. On the day before infection, cells were freshly plated at $40 \%$ confluence in 6-well plates, and infection was performed as reported previously (28).

To assess the multiplicity of infection (MOI) and the expression of the target protein, BGC-823 cells were infected with adenovirus at an MOI of 25, 50, 100, 200 and $500 \mathrm{pfu} /$ cell for $48 \mathrm{~h}$, and expression of $\beta$-Gal and PKG II in Ad-LacZand Ad-PKG II-infected cells was detected by X-Gal staining and Western blotting with the PKG II antibody, respectively.

Western blotting. The cells were harvested and homogenized with an ultrasonic homogenizer in sample buffer. The homogenates were heated in boiling water for $5 \mathrm{~min}$, separated by SDS-polyacrylamide gel and blotted onto a polyvinyl difluoride (PVDF) membrane. The PVDF membrane was blocked with 3\% bovine serum albumin (BSA) in TBS-T for $1 \mathrm{~h}$ at room temperature (RT). Incubation with the primary antibody was conducted overnight at $4^{\circ} \mathrm{C}$, and incubation with the secondary antibody was for $1 \mathrm{~h}$ at RT, with three washes after each incubation. ECL reagents were used to reveal the positive bands on the membrane.

MTT assay. Ten thousand cells (in $100 \mu \mathrm{l}$ complete DMEM) were seeded in one well of a 96-well plate. After attachment, the cells were infected with Ad-LacZ and Ad-PKG II at an MOI of $100 \mathrm{pfu} / \mathrm{cell}$ for $24 \mathrm{~h}$. The cells were then washed and serum-starved overnight. Thereafter, the cells were incubated in the presence or absence of 100 or $250 \mu \mathrm{M} 8$-pCPT-cGMP for $24 \mathrm{~h}$. Approximately $20 \mu \mathrm{l}$ of MTT dye $(5 \mathrm{mg} / \mathrm{ml})$ was added to each well, and the plate was incubated for $4 \mathrm{~h}$. Dimethylsulfoxide (DMSO) (150 $\mu \mathrm{l})$ was added to the wells to dissolve the formazan crystals, and the optical density (OD) at $490 \mathrm{~nm}$ was measured. Data were presented as a percentage of control proliferation, with $\mathrm{P}<0.05$ considered to be significant.

BrdU incorporation assay. Ten thousand cells were seeded on a dual-chamber slide. After attachment, the cells were infected with Ad-LacZ and Ad-PKG II at an MOI of $100 \mathrm{pfu} /$ cell for $24 \mathrm{~h}$. Thereafter, cells were incubated in the presence or absence of $250 \mu \mathrm{M} 8$-pCPT-cGMP for $24 \mathrm{~h}$. BrdU $(200 \mu \mathrm{M})$ was added to the culture medium during the last $6 \mathrm{~h}$ of the incubation. The cells were washed in PBS, fixed with freshly prepared $4 \%$ (40 g/l) paraformaldehyde in PBS at $4^{\circ} \mathrm{C}$ overnight, and permeabilized with $0.3 \%$ Triton X-100 in PBS for $10 \mathrm{~min}$. DNA was digested with $0.5 \mathrm{U} / \mu$ l DNase 1 for $30 \mathrm{~min}$ at $37^{\circ} \mathrm{C}$. After being washed with PBS and blocked with $30 \mathrm{~g} / \mathrm{l} \mathrm{BSA}$ in PBS for $1 \mathrm{~h}$, the cells were incubated with BrdU (1:200) and PKG II (1:200) antibodies, followed by FITC (1:50) or Cy3 (1:1000) labeled secondary antibodies for $1 \mathrm{~h}$ at RT respectively. Nuclei were stained with $0.2 \mu \mathrm{mol} / 1$ Hoechst 33342 for $10 \mathrm{~min}$. The fluorescence of FITC (green), Cy3 (red) and Hoechst 33342 (blue) was observed and recorded under a fluorescence microscope with a CCD camera (Leica).

Colony formation assay. DNA grade agarose (1\%) was melted by heating in a microwave oven and cooled to $40^{\circ} \mathrm{C}$ in a water bath. DMEM (2X) containing 20\% NBCS was warmed to $40^{\circ} \mathrm{C}$ in the same water bath. Equal volumes of the two solutions were mixed to give a solution of $0.5 \%$ agarose, $1 \mathrm{X}$ DMEM and 10\% NBCS (base agar). The solution $(1.5 \mathrm{ml})$ was poured into a $35-\mathrm{mm}$ cell culture dish and allowed to set at RT. A solution of $0.7 \%$ agarose, 2X DMEM and $20 \%$ NBCS (top agar) was made in the same way. The suspension of infected or non-infected BGC-823 cells was mixed with the top agar solution to make a final solution with 5,000 cells $/ \mathrm{ml}$, and $1 \mathrm{ml}$ was added to each dish. The dish was incubated in a cell culture incubator for 10-14 days, and 8-pCPT-cGMP was added every two days. Colony formation was observed and recorded under a reverse microscope.

Tumor-bearing nude mouse model. SPF grade BALB/c nude mice with a weight of $18.76 \pm 1.34 \mathrm{~g}$ were maintained in a super-clean biological laminar flow shelf at $25^{\circ} \mathrm{C}$ and $60-70 \%$ humidity, with a standard rodent diet and water. BGC-823 cells infected with Ad-LacZ or Ad-PKG II were injected subcutaneously into their forequarter. Each mouse received a $200-\mu 1$ cell suspension containing $2 \times 10^{6}$ cells. The nude mice were divided into Ad-LacZ, Ad-PKG II and Ad-PKG II + cGMP groups (5 mice/group). To enhance the infection rate, when nodules $(5 \times 5 \mathrm{~mm})$ appeared, $100 \mu \mathrm{l}$ of the adenoviral solution $(\mathrm{MOI}=100)$ was injected intratumorally at several points. One week after injection, $100 \mu \mathrm{l}$ PBS (for the Ad-LacZ and Ad-PKG II groups) and 8-pCPT-cGMP solution (250 $\mu \mathrm{M}$ for the Ad-PKG II + cGMP group) were injected intratumorally at several points. This process was repeated every two weeks for six weeks. At the end of the experiment, the tumors were excised, and their weights and volumes were measured. The largest (a) and smallest (b) diameter of each tumor was measured with Vernier calipers, and the tumor volume was calculated by the formula $\mathrm{V}=\mathrm{ax} \mathrm{b}^{2} \times 0.5236$.

Flow cytometric analysis of the cell cycle. BGC-823 cells were infected with Ad-LacZ or Ad-PKG II and treated with or without 8-pCPT-cGMP. The cells were washed two times with PBS and suspended in $4 \mathrm{ml}$ of $75 \%$ ethanol. Before analysis, the cells were washed two times with PBS and incubated with RNase A $(10 \mu \mathrm{g} / \mathrm{ml})$ at $37^{\circ} \mathrm{C}$ for $30 \mathrm{~min}$. After being stained 
A

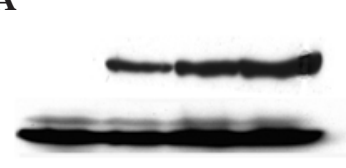

B

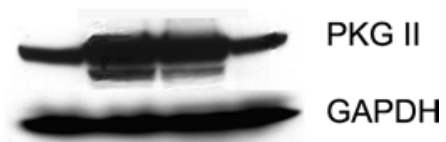

C

D

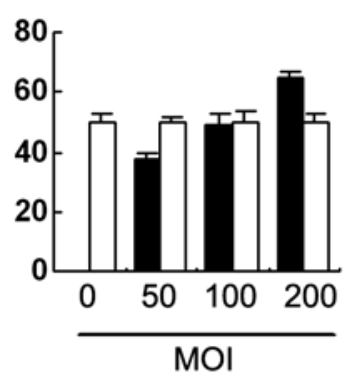

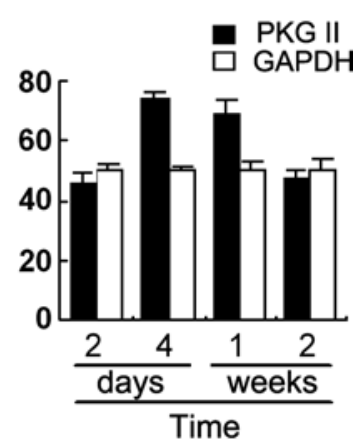

Figure 1. Expression of PKG II in the BGC-823 cell line. The human gastric cancer cell line BGC-823 was infected with Ad-PKG II at a multiplicity of infection (MOI) of 0, 50, 100 or $200 \mathrm{pfu} / \mathrm{cell}$ for $48 \mathrm{~h}$ (A), and at an MOI of 100 for various time periods ( 2 and 4 days, 1 and 2 weeks) (B). Expression of PKG II was detected by Western blotting. Densitometric analysis of the bands is shown (C and D). Each bar represents the mean \pm SD obtained from three independent experiments.

with PI-staining solution in the dark for $30 \mathrm{~min}$ at RT, the cells were analyzed by flow cytometry.

Statistical analysis. Data are presented as the mean \pm standard deviation (SD); $n=3$. A one-way ANOVA was used to determined whether the results had statistical significance. In some cases, the Student's t-test was used for comparing two groups. The level of statistical significance was set at $\mathrm{P}<0.05$. All other results are representative experiments that were reproduced at least three times.

\section{Results}

Adenovirus-mediated LacZ and PKG II gene transfer into BGC-823 cells. Infection with Ad-LacZ and Ad-PKG II resulted in highly efficient homogeneous expression of LacZ and PKG II genes. $\beta$-Gal staining showed that the infection rate was $41 \pm 7,87 \pm 13$ and $94 \pm 18 \%$ at an MOI of 50,100 and $200 \mathrm{pfu} / \mathrm{cell}$, respectively. The MOI of $100 \mathrm{pfu} / \mathrm{cell}$ was used in the subsequent experiments. Western blotting with an antibody against PKG II was used to detect the expression of PKG II in BGC-823 cells infected with Ad-PKG II at an MOI of $100 \mathrm{pfu} / \mathrm{cell}$. The result showed that, in the mock-infected cells, the expression level was extrememly low (Fig. 1A). However, in cells infected with Ad-PKG II, the expression of PKG II dose-dependently increased (Fig. 1A). The time course of the expression of PKG II was also detected. Expression reached the highest level on the fourth day after infection, and remained at a high level for at least two weeks (Fig. 1B).

PKG II decreases the number of live cells during culture. The number of live cells was determined by the MTT assay (Fig. 2). In the group infected with Ad-PKG II and treated with 8-pCPT-cGMP, the number of live cells was clearly

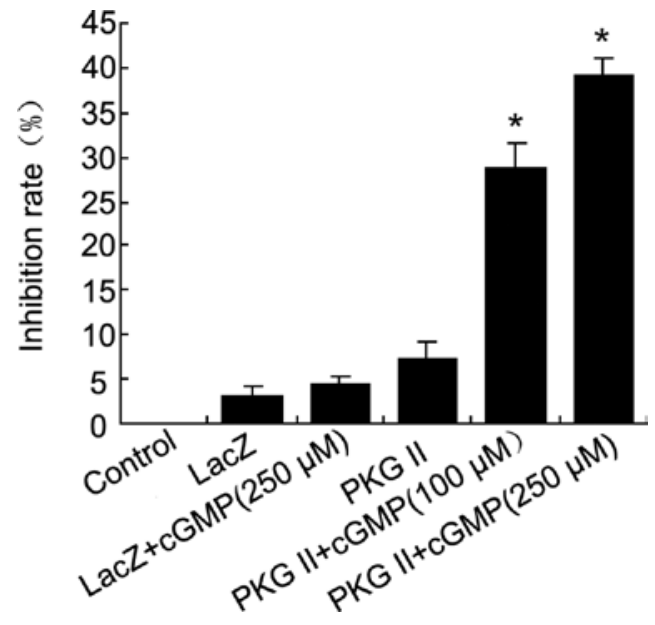

Figure 2. Results of the MTT assays. Data are the mean \pm SD from three independent experiments each performed in duplicate $\left({ }^{*} \mathrm{P}<0.05\right.$ compared with mock, Ad-LacZ and Ad-PKG II infection alone). LacZ, Ad-LacZ-treated group; PKG II, Ad-PKG II-treated group; PKG II + cGMP, Ad-PKG II + cGMP-treated group.

decreased. The stimulation of Ad-PKG II-infected cells with $250 \mu \mathrm{M} 8$-pCPT-cGMP produced an $\sim 39 \%$ decrease in the number of live cells compared to the untreated control cells $(\mathrm{P}<0.05)$ (Fig. 2). There was no difference between the Ad-LacZ- and Ad-PKG II-infected cells (4.8 vs. 6.0\%), suggesting that the activation of PKG II is necessary for its antiproliferative effect on BGC-823 cells.

PKG II inhibits the DNA synthesis of individual cells. In order to obtain direct evidence regarding the effect of PKG II on cell division, BrdU incorporation was performed to assess the rates of DNA synthesis in BGC-823 cells. Fig. 3 demonstrates that, in cells infected with Ad-PKG II and treated with 8-pCPTcGMP $(250 \mu \mathrm{M})$ for $24 \mathrm{~h}$, DNA synthesis was significantly decreased. However, infection with Ad-PKG II alone had no obvious effect on BrdU incorporation. The results suggest that both the expression and activation of PKG II are required for the inhibition of DNA synthesis of the cells.

PKG II inhibits PCNA expression. To further evaluate the effect of PKG II on cell proliferation, the expression of early cell cycle protein PCNA, which is up-regulated in the late $\mathrm{G}_{1}$ phase, was detected by Western blotting. PCNA protein levels were three times higher in EGF-treated cells than in the control cells (Fig. 4). Infection with Ad-PKG II and stimulation with 8-pCPT-cGMP induced a $42 \%$ decrease in PCNA expression compared to the EGF-treated cells $(\mathrm{P}<0.01)$ (Fig. 4).

PKG II inhibits anchorage-independent growth of BGC-823 cells. To investigate whether PKG II inhibits anchorage-independent growth of BGC-823 cells, infected or non-infected BGC-823 cells were grown in soft agarose, and PKG II activation was induced with 8-pCPT-cGMP. After a 2-week culture, random fields were selected, and colony formation was observed under a reverse microscope. Cell colonies emerged in all cell dishes, but the colonies from the cells infected with Ad-PKG II and treated with 8-pCPT-cGMP 

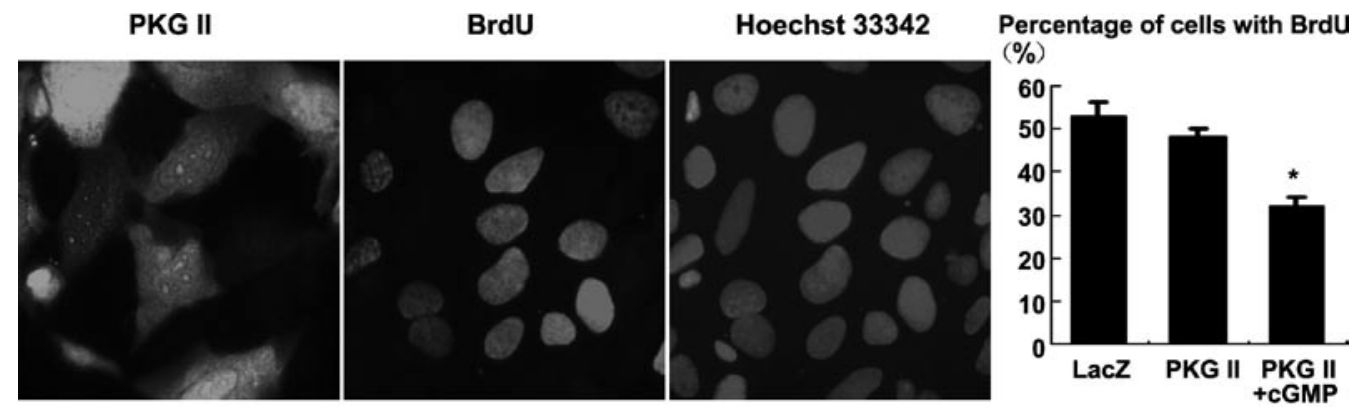

Figure 3. DNA synthesis of individual cells. The cells were triply stained with an antibody against PKG II, an antibody against BrdU, and Hoechst 33342 . Three high-power fields were randomly selected, and the percentage of cells with BrdU incorporation was calculated. The mean \pm SD of three independent experiments is presented ( ${ }^{*} \mathrm{P}<0.01$, compared with Ad-LacZ infection and Ad-PKG II infection alone).

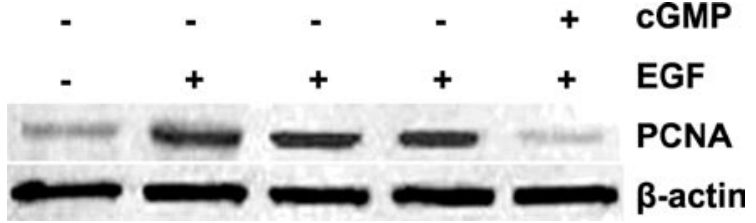

Figure 4. Expression of PCNA in the BGC-823 cell line. The cells were treated as described in Materials and methods. The cell extract was constructed, and PCNA was detected with Western blotting. The EGF-induced expression of PCNA was significantly decreased in Ad-PKG II-infected and 8-pCPT-cGMP-treated cells compared to the cells infected with Ad-LacZ or Ad-PKG II alone.
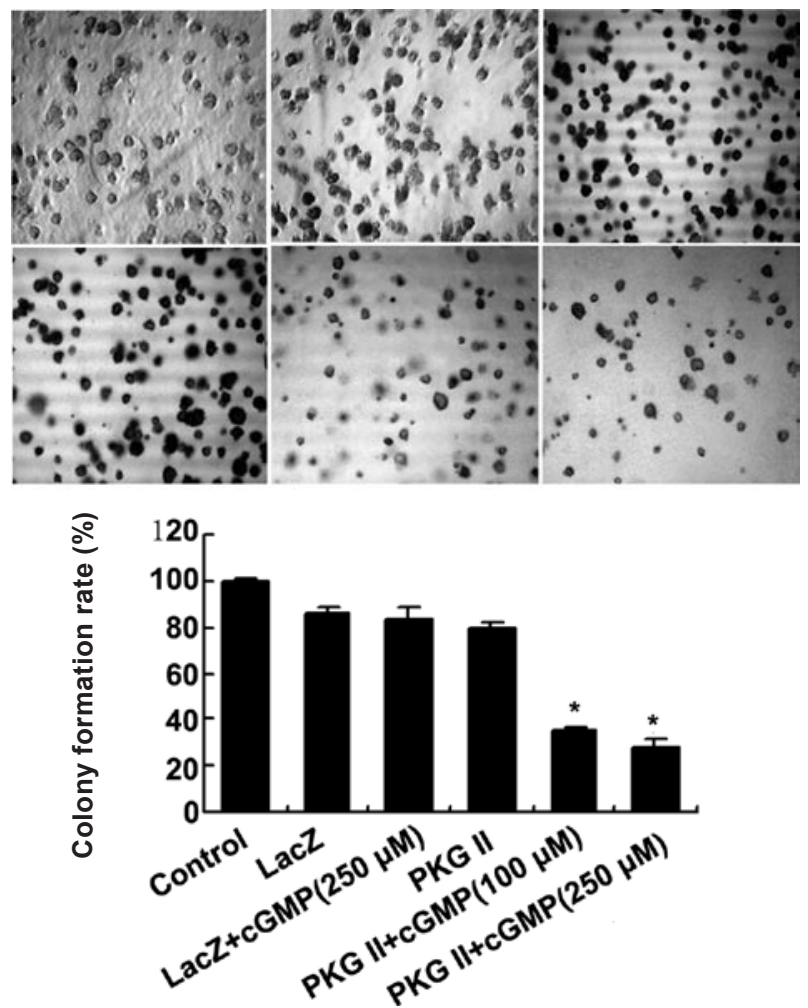

Figure 5. The effect of PKG II on the anchorage-independent growth of BGC-823 cells. BGC-823 cells were first infected with Ad-PKG II or Ad-LacZ and then cultured in soft agarose. 8-pCPT-cGMP and placebo were added every two days. Upper panels: In the presence of 8-pCPT-cGMP, Ad-PKG II-infected cells exhibited considerable inhibition of colony formation, while infection with Ad-LacZ or Ad-PKG II alone had no inhibitory effect on colony formation compared to the control group. Lower panels: The ratio of colony formation (number of colonies divided by the number of total seeded cells in the randomly selected fields) was calculated. The results are the mean \pm SD of three independent experiments (" $\mathrm{P}<0.05$ compared with the control). were significantly fewer and smaller than those of the control cells. The colony formation ratio was calculated to represent the anchorage-independent growth of the cells (Fig. 5).

PKG II inhibits tumor growth in immunocompromised nude mice. To investigate the antitumor effect of PKG II in vivo, BGC-823 cells were infected with Ad-LacZ and Ad-PKG II, suspended in serum-free medium and subcutaneously implanted into nude mice. To enhance the infection and activate PKG II, virus and 8-pCPT-cGMP were administered as described in Materials and methods. Fifty days later, the mice were sacrificed, the tumors were excised, and the weights and volumes were measured. Tumor volumes were smaller and blood supplies were poorer in the Ad-PKG II + 8-pCPTcGMP group than in the Ad-LacZ- and Ad-PKG II-infected groups (Fig. 6). The mean weight of the tumors in the three groups was $1.07 \pm 0.09,2.57 \pm 0.13$ and $1.95 \pm 0.07 \mathrm{~g}$, and the mean volume was $1.15,3.40$ and $2.51 \mathrm{~cm}^{3}$, respectively. There was significant inhibition of tumor growth in the Ad-PKG II + cGMP group compared with the Ad-LacZ- and Ad-PKG II-treated groups $(\mathrm{P}<0.01)$ (Fig. 6).

PKG II causes cell cycle arrest. BGC-823-cells were infected with Ad-PKG II, stimulated with 8-pCPT-cGMP for $24 \mathrm{~h}$, and stained with PI. The DNA profiles of the cells were analyzed by flow cytometry. The results showed that infection with Ad-LacZ did not increase the number of cells in the $G_{1}$ phase. However, PKG II infection plus 8-pCPT-cGMP treatment caused a shift from the $S$ phase into the $G_{1}$ phase. In particular, PKG II activation increased the $\mathrm{G}_{2} / \mathrm{M}$ event with a concomitant decrease in events in the $\mathrm{S}$ phase of the cell cycle (Fig. 7).

\section{Discussion}

Research has shown that cGMP-dependent signaling pathways exert an important effect on the biological activity of tumor cells (22). However, only the role of PKG I in tumorigenesis has been well-studied, and this kinase has been identified as a tumor suppressor (17-19). Even though data suggest that PKG II may also be a potential tumor suppressor $(23,29)$, a systematic study regarding its effect on the biological activity of cancer cells has yet to be conducted. In this study, serial assays and methods were applied to confirm the antiproliferative effect of PKG II. 

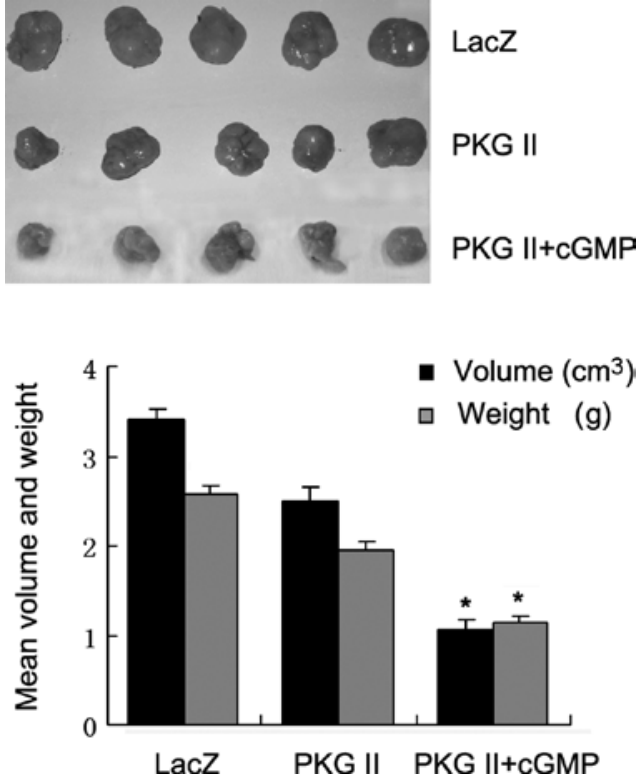

Figure 6. Effects of PKG II on tumor growth in immunocompromised nude mice. BGC-823-infected cells were subcutaneously injected into nude mice, and Ad-PKG II, Ad-LacZ and 8-pCPT-cGMP were administered as described in Materials and methods. The tumors were excised, and the volumes and weights of the tumors of the different groups were calculated.

Since the expression and activity of PKG II are clearly lower in cancer cell lines than in normal cells (27), introducing the exogenous PKG II gene to increase its expression and activity may serve as an effective method for studying its role in tumorigenesis. For this purpose, we selected adenoviral vectors encoding the PKG II gene to infect gastric carcinoma cell lines. Several gastric cancer cell lines, including AGS, SGC-7901 and BGC-823, were infected with Ad-LacZ and Ad-PKG II, and the results showed that BGC-823 was the most sensitive to adenoviral infection. $\beta$-Gal staining showed that the rate of Ad-LacZ infection was higher than $90 \%$. Western blotting showed that PKG II expression was significantly higher in the Ad-PKG II-infected cells than in the control cells, and was maintained at a high level for at least two weeks. On the other hand, evidence has revealed that BGC-823 is a highly malignant cell line with strong proliferation capacity and migration activity (30). Therefore, the combination of both BGC-823 cells and the Ad-PKG II construct provided an ideal model for studying the role of PKG II in tumorigenesis.

First, the MTT assay showed that the number of live cells was significantly decreased when the cells were infected with Ad-PKG II and treated with 8-pCPT-cGMP. However, since this assay could not determine whether the cell decrease was caused by the inhibition of proliferation or the induction of apoptosis (31), other methods were applied to provide direct evidence of the antiproliferative effect of PKG II. The BrdU incorporation assay was performed to assess the DNA synthesis rate of BGC-823 cells, and the results revealed that the activation of PKG II with 8-pCPT-cGMP inhibited DNA synthesis in individual cells. PCNA is an early cell cycle protein. It acts as a processivity factor for DNA polymerase $\delta$ in eukaryotic cells, and is up-regulated in the late $\mathrm{G}_{1}$ phase. Western blotting was used to detect the expression of this proliferating marker protein, and demonstrated that PKG II activation inhibits the EGF-induced increase in PCNA expression. Therefore, these
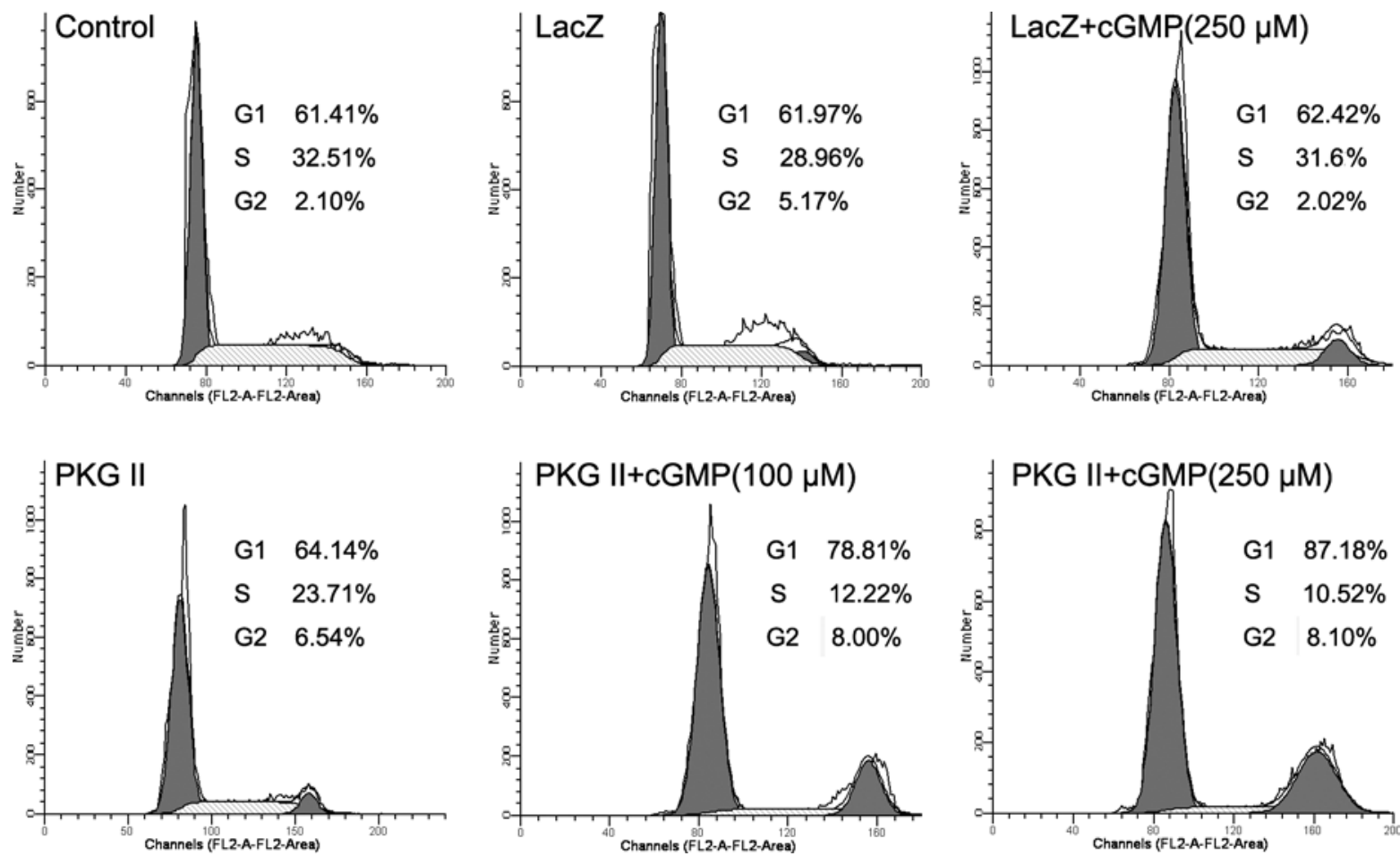

Figure 7. Cell cycle analysis. BGC-823 cells were infected with Ad-PKG II and cultured in the absence or presence of 8-pCPT-cGMP. The cells were collected, and the proportion of cells in each phase of the cell cycle was detected by flow cytometry as described in Materials and methods. In the Ad-PKG II infection and 8-pCPT-cGMP treatment groups, there were fewer cells in the $\mathrm{S}$ phase and more in the $\mathrm{G}_{1}$ phase (*P<0.05 compared with control cells). Values are the mean \pm SD of three different assays, each performed in triplicate. 
assays confirmed that the increased PKG II activity inhibited the proliferation of the cells.

Several assays were also carried out to investigate the effect of PKG II on additional proliferation-related features of BGC-823 cells. Colony formation in soft agar was performed to analyze the effect of PKG II on the anchorage-independent growth [a unique feature of cancer cells (32)] of BGC-823 cells. The results showed that the activation of PKG II by 8-pCPT-cGMP $(250 \mu \mathrm{M})$ significantly inhibited the colony formation of BGC-823 cells. The in vivo study showed that the overexpression of PKG II by Ad-PKG II infection and local administration of 8-pCPT-cGMP significantly suppressed the growth of BGC-823 cells in immunocompromised nude mice. The effect of PKG II on the cell cycle was analyzed by flow cytometry. The results revealed that the activation of PKG II did not cause apoptosis, since no change in the number of cells stained with PI was observed (data not shown). However, substantial cell cycle arrest at the $G_{1}$ phase and a decrease in $\mathrm{S}$ phase cells in the Ad-PKG II/8-pCPT-cGMP-treated cells was observed.

Our results strongly suggest that PKG II is a potential anticancer factor. This sheds new light on the study of tumorigenesis and provides a new strategy for the gene therapy of gastric carcinoma. However, further studies are needed to elucidate the molecular events and signal transductions initiated by PKG II activation during its antitumor process.

\section{Acknowledgements}

This study was supported by the National Natural Science Foundation of China (no. 30470891), and by a Jiangsu University Innovation Grant. We thank Dr Gerry Boss and Dr Renate Pilz of the University of California, San Diego, USA, for the kind gift of the adenoviral constructs.

\section{References}

1. Alberts SR, Cervantes A and van de Velde CJ: Gastric cancer: epidemiology, pathology and treatment. Ann Oncol 2: 31-36, 2003.

2. Catalano V, Labianca R, Beretta GD, Gatta G, de Braud F and van Cutsem E: Gastric cancer. Crit Rev Oncol Hematol 71: 127-164, 2009.

3. Hamilton JP and Meltzer SJ: A review of the genomics of gastric cancer. Clin Gastroenterol Hepatol 4: 416-425, 2006.

4. Orstavik S, Natarajan V, Taskén K, Jahnsen T and Sandberg M: Characterization of the human gene encoding the type I alpha and type I beta cGMP-dependent protein kinase (PRKG1) Genomics 42: 311-318, 1997.

5. Orstavik S, Solberg R, Taskén K, et al: Molecular cloning, cDNA structure and chromosomal localization of the human type II cGMP-dependent protein kinase. Biochem Biophys Res Commun 220: 759-765, 1996.

6. Wolfe L, Corbin JD and Francis SH: Characterization of a novel isozyme of cGMP-dependent protein kinase from bovine aorta. J Biol Chem 264: 7734-7741, 1989.

7. Gamm DM, Francis SH, Angelotti TP, Corbin JD and Uhler MD: The type II isoform of cGMP-dependent protein kinase is dimeric and possesses regulatory and catalytic properties distinct from the type I isoforms. J Biol Chem 270 27380-27388, 1995

8. Hou Y, Gupta N, Schoenlein P, Wong E, Martindale R, Ganapathy V and Browning D: An anti-tumor role for cGMPdependent protein kinase. Cancer Lett 240: 60-68, 2006.

9. Hou Y, Wong E, Martin J, Schoenlein PV, Dostmann WR and Browning DD: A role for cyclic-GMP dependent protein kinase in anoikis. Cell Signal 18: 882-888, 2006.
10. Shimojo T, Hiroe M, Ishiyama $S$, Ito $H$, Nishikawa $T$ and Marumo F: Nitric oxide induces apoptotic death of cardiomyocytes via a cyclic-GMP-dependent pathway. Exp Cell Res 247: 38-47, 1999.

11. Segawa K, Minami K, Shiga Y, Shiraishi M, Sata T, Nakashima Y and Shigematsu A: Inhibitory effects of nicorandil on rat mesangial cell proliferation via the protein kinase $\mathrm{G}$ pathway. Nephron 87: 263-268, 2001

12. Loweth AC, Williams GT, Scarpello JH and Morgan NG: Evidence for the involvement of cGMP and protein kinase $\mathrm{G}$ in nitric oxide-induced apoptosis in the pancreatic B-cell line, HIT-T15. FEBS Lett 400: 285-288, 1997.

13. Aoshiba K, Yasui S, Hayashi M, Tamaoki J and Nagai A: Role of p38-mitogen-activated protein kinase in spontaneous apoptosis of human neutrophils. J Immunol 162: 1692-1700, 1999.

14. Brunetti M, Mascetra N, Manarini S, et al: Inhibition of cGMP-dependent protein kinases potently decreases neutrophil spontaneous apoptosis. Biochem Biophys Res Commun 297: 498-501, 2002.

15. Haanen C: Sulindac and its derivatives: a novel class of anticancer agents. Curr Opin Investig Drugs 2: 677-683, 2001.

16. Liu L, Li H, Underwood T, et al: Cyclic GMP-dependent protein kinase activation and induction by exisulind and CP461 in colon tumor cells. J Pharmacol Exp Ther 299: 583-592, 2001.

17. Browing DD: Protein kinase $\mathrm{G}$ as a therapeutic target for the treatment of metastatic colorectal cancer. Expert Opin Ther Targets 12: 367-376, 2008.

18. Mujoo K, Sharin VG, Martin E, et al: Role of soluble guanylyl cyclase-cyclic GMP signaling in tumor cell proliferation. Nitric Oxide: Nov, 2009 (E-pub ahead of print).

19. Wang $\mathrm{S}$ and Li Y: Expression of constitutively active cGMP-dependent protein kinase inhibits glucose-induced vascular smooth muscle cell proliferation. Am J Physiol Heart Circ Physiol 297: H2075-H2083, 2009.

20. Lincoln TM, Dey N and Sellak H: Invited review: cGMP-dependent protein kinase signaling mechanisms in smooth muscle: from the regulation of tone to gene expression. J Appl Physiol 91: 1421-1430, 2001.

21. Vaandrager AB, Edixhoven M and Bot AG: Endogenous type II cGMP-dependent protein kinase exists as a dimer in membranes and can be functionally distinguished from the type I isoforms. J Biol Chem 272: 11816-11823, 1997.

22. Hofmann F: The biology of cyclic GMP-dependent protein kinases. J Biol Chem 280: 1-4, 2005.

23. Cook AL and Haynes JM: Protein kinase G II-mediated proliferative effects in human cultured prostatic stromal cells. Cell Signal 16: 253-261, 2004.

24. Cook AL and Haynes JM: Phosphorylation of the PKG substrate, vasodilator-stimulated phosphoprotein (VASP), in human cultured prostatic stromal cells. Nitric Oxide 16: 10-17, 2007.

25. Chiche JD, Schlutsmeyer SM, Bloch DB, et al: Adenovirusmediated gene transfer of cGMP-dependent protein kinase increases the sensitivity of cultured vascular smooth muscle cells to the antiproliferative and pro-apoptotic effects of nitric oxide/cGMP. J Biol Chem 273: 34263-34271, 1998.

26. Hood J and Granger HJ: Protein kinase G mediates vascular endothelial growth factor-induced Raf-1 activation and proliferation in human endothelial cells. J Biol Chem 273: 23504-23508, 1998.

27. Yang SQ, Chen YC, Wang Y and Tao Y: Expression of cGMP dependent protein kinase II in cancer cell lines was obviously decreased. J Jiangsu Univ (Medicine edition) 18: 1-5, 2008.

28. Rangaswami H, Marathe N, Zhuang S, et al: Type II cGMP-dependent protein kinase mediates osteoblast mechanotransduction. J Biol Chem 284: 14796-14808, 2009.

29. Chikuda H, Kugimiya F, Hoshi K, et al: Cyclic GMP-dependent protein kinase II is a molecular switch from proliferation to hypertrophic differentiation of chondrocytes. Genes Dev 18: 2418-2429, 2004

30. Li QF, Ou Yang GL, Li CY and Hong SG: Effects of tachyplesin on the morphology and ultrastructure of human gastric carcinoma cell line BGC-823. World J Gastroenterol 6: 676-680, 2000.

31. Ulukaya E, Ozdikicioglu F, Oral AY and Demirci M: The MTT assay yields a relatively lower result of growth inhibition than the ATP assay depending on the chemotherapeutic drugs tested. Toxicol In Vitro 22: 232-239, 2008.

32. Horowitz D and King AG: Colorimetric determination of inhibition of hematopoietic progenitor cells in soft agar. Immunol Methods 244: 49-58, 2000. 